\title{
ONLINE LEARNING MEDIA IN HIGHER EDUCATION IN THE NEW NORMAL ERA
}

\author{
Nurhanna Harahap, Muhammad Rusli \\ Universitas AI Washliyah (UNIVA) Labuhanbatu \\ Rantauprapat, Indonesia \\ E-mail: nurhanna050@gmail.com
}

Received: 2021-06-16

Accepted: 2021-11-27

\begin{abstract}
This study aims to determine and describe (1) online learning media used in the teaching and learning process in the new normal era, (2) students' understanding of the use of online learning media, (3) students' preference of the way of communication, and (4) students' preference of material form. The participants of this research are the students of English Education Study Program at Universitas Al Washliyah (UNIVA) Labuhanbatu. The instrument of the research is questionnaire distributed via Google Form. Data analysis technique used in this study consists of data colletion, data reduction, data display, and drawing conclusion. The result shows that the most frequently used online learning media are WhatsApp and Google Classroom. Almost all students understand how to operate WhatsApp, Zoom, and Email. As many as $47 \%$ students choose two-way semi communication in teaching learning process. Using video as the material form in teaching learning proces is the most preferred by students.
\end{abstract}

Keywords: online Learning, online Learning Media, New Normal, Google Classroom

\section{Introduction}

The teaching and learning process has changed since the Covid-19 pandemic emerged. Previously, the teaching and learning process was still carried out face-to-face in class, now face-to-face meetings have been restricted. It was done as an effort to break the chain of spreading covid-19. The Indonesian government through the Ministry of Education and Culture of the Republic of Indonesia is looking for solutions so that the teaching and learning process can still be carried out even though in different ways. Through Circular Letter Number 4 of 2020, concerning the Implementation of Education in the Coronavirus Disease (Covid-19) Emergency Period that the teaching and learning process is carried out from home. The Ministry of Education and Culture stipulates that education in Indonesia must continue to be implemented but by system of Study from Home (SFH) (Putro et. al., 2020).

UNIVA Labuhanbatu's English education study program responded to this call by implementing study from home or online learning. The study from home system is one of the standard systems in the New Normal Era. This system presents a challenge to lecturer and students in UNIVA Labuhanbatu's English education study program. The challenges faced are the same as those mentioned by Latip. The educator's challenge is how to convey learning material to students so that students are able to understand learning material, 
while the student's challenge is mental readiness to adapt to the learning system from home (Latip, 2020).

This challenge also demands UNIVA Labuhanbatu's English education study program to integrate digital technology into teaching learning process. There are some online learning media such as Google Classroom, Google Meet, WhatsApp, Zoom, etc. This media is very helpful to help lecturer to manage their course.

Several studies have shown that the use of online learning media has a positive impact on the teaching and learning process. For example, in organizing learning in English primary and secondary schools. Online learning media helps students to access various kinds of learning resources, helps students learn independently, helps students do collaborative learning, and helps students reflect on and assess their learning. Other research states that the Cisco WebEx Meeting, Google Classroom, and WhatsApp gained highly positive agreement on all criteria for the EFL students.

The difference between this study and previous research is the sample. In previous studies, the samples were English primary and secondary schools, so in this study, the sample are English higher education students.

Based on the explanation above, this study aims to determine online learning media used in the teaching and learning process in the new normal era, to describe students' understanding of the use of online learning media, to determine students' preference of the way of communication, and to determine students' preference of material form. The source of data is the students of English Education Study Program at Universitas Al Washliyah (UNIVA) Labuhanbatu.

\section{Literature Review}

The learning system in Indonesia during the COVID-19 pandemic uses an online learning system. Online learning is a teaching and learning process that is carried out using a network (Hadianti and Arisandi, 2020). Online learning as an approach, with web media, which is used by lecturers to deliver teaching materials to remote students. Students, lecturer, references, and technology are the commponents that support the achievement of online learning success.

Online learning can increase the role of students in the learning process. The most important thing in applying online learning to students is to pay attention to various aspects so that learning objectives are achieved. Online learning includes five important things, namely 1 ) the content presented has relevance to the specific learning objectives to be achieved; 2) using learning methods through examples and exercises to help students learn; 3) using media such as pictures and words to present content and methods; and 4) developing and building new knowledge and skills according to individual goals and organizational improvement (Abidin \& Arizona, 2020).

Online learning media is very useful when teaching learning process is done in distance learning. There are some online learning media, such as WhatsApp, Google Classroom, Zoom, etc. WhatsApp is a credit-free application that is used to send messages. This application is the same as email or browsing web using an internet package. There are many advantages that can be obtained by using WhatsApp, starting from sending messages, pictures, videos, documents, and so on (Sahid, 2020). Google Classroom is very helpful because it can be accessed anytime and anywhere (Maulana, 2020). Lecturers easily create 
materials and assignments by using Google Classroom. Material can be in the form of files or links. As well as students, they can directly type their answers either via cellphone or leptop. There are many benefits that can be felt by users of Google Classroom. Two of them are (1 material creation can be done only by uploading files or links and ( 2 uploading tasks can only be done by uploading files or photos. Zoom application is a solution for holding meetings virtually without having to meet face to face in digital era (Pratiwi, Afandi, \& Wahyuni, 2019). The type of meeting used is via video conference. Meeting participants can interact directly and can also provide direct feedback (Nashir, 2020). There are several advantages to the zoom application (Melati, 2020). Three of them are (1 up to 100 meeting participants, (2 meeting participants can send message during the meeting, ( 3 meeting participants can display documents, pictures, etc. through the share screen.

To achieve learning goals through online learning, a communication system is needed. There are 3 forms of communication with long-distance systems, namely 1) one-way, 2) twoway, and 3) semi two-way communication. One-way communication is where the sender and receiver of information cannot establish continuous communication through the same medium, for example, the use of video in teaching learning proces. In two-way communication, the sender and receiver of information can establish continuous communication through the same medium. This form of communication occurs when the lecturer and students use zoom in learning and teaching proces. Semi-two-way communication is where the sender and receiver of information communicate alternately, but still continuously. Lecturer and students use this form when they are using WhatsApp. They communicate alternately and continuously in chat room.

\section{Research Method}

This research used descriptive qualitative research. The participants of this research were the students of English Education Study Program at Universitas Al Washliyah (UNIVA) Labuhanbatu. The research subjects was carried out using purposive sampling technique. The criteria for the students involved in this study were students of English Education UNIVA Labuhanbatu who were active in the Even Semester of the Academic Year 2020/2021 who were taking online learning. The instrument of the research was questionnaire. Students used Google Form to fill out the questionnaire. The data analysis technique used in this research is qualitative analysis that consists of data collection, data reduction, data presentation, and drawing conclusions.

\section{Results and Discussion}

The questionnaire distributed to students of the UNIVA Labuhanbatu English Education study program in semester II, IV, and VI even semesters of the 2020/2021 academic year. There are 26 students. However, only 17 students responded. Description of respondents is in Table 1.

\begin{tabular}{|c|c|}
\hline Semester & Number of Respondent \\
\hline II & 4 \\
\hline IV & 6 \\
\hline VI & 7 \\
\hline
\end{tabular}

Tabel 1. Description of Respondent 
Semester II consisted of four students, semester IV consisted of six students, and semester VI consisted of seven students.

\subsection{Results}

There were some results found. The first result is about the use of online learning media.

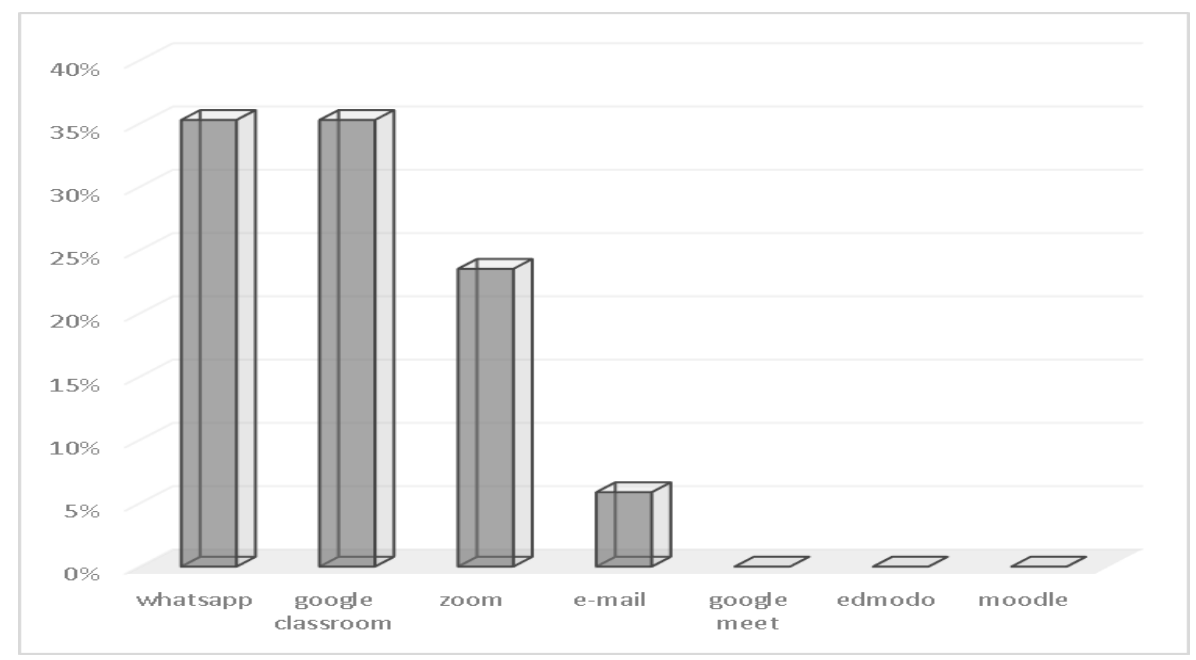

Figure 1. The use of online learning platform

Figure 1 shows that $35 \%$ students used WhatsApp as online learning media. Students used Google Classroom as online learning media is about $35 \%$. Zoom was about $24 \%$ used in teaching learning process. 6\% students used e-mail. Google Meet, Edmodo, and Moodle were never been used.

The second result is about whether the students understand or do not understand how to use those online learning platforms.

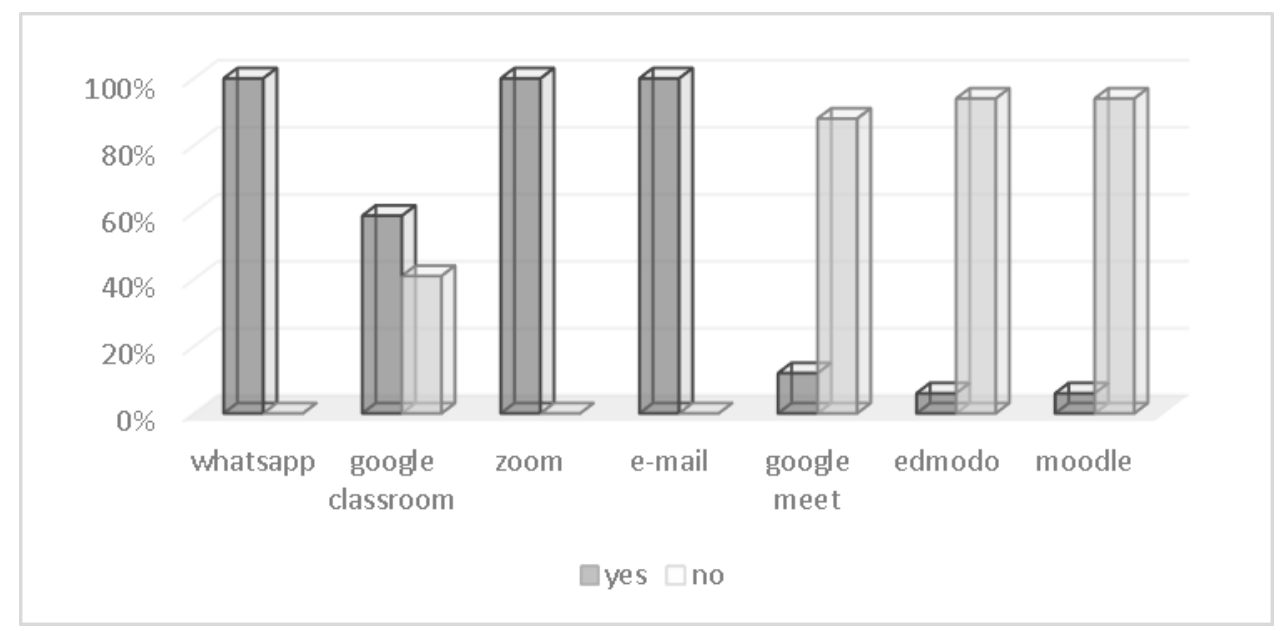

Figure 2. Students' understanding of the use of online learning platform

Figure 2 shows 100\% students understand how to use WhatsApp. 59\% students understand how to use Google Classroom while $41 \%$ do not understand. $100 \%$ students understand how to operate Zoom application. 100\% students understand using E-mail. 12\% students understand operating Google Meet and $88 \%$ do not understand. $6 \%$ students 
understand operating Edmodo and Moodle while 94\% do not understand operating Edmodo and Moodle.

The third result shows the students' preference of the way of communication.

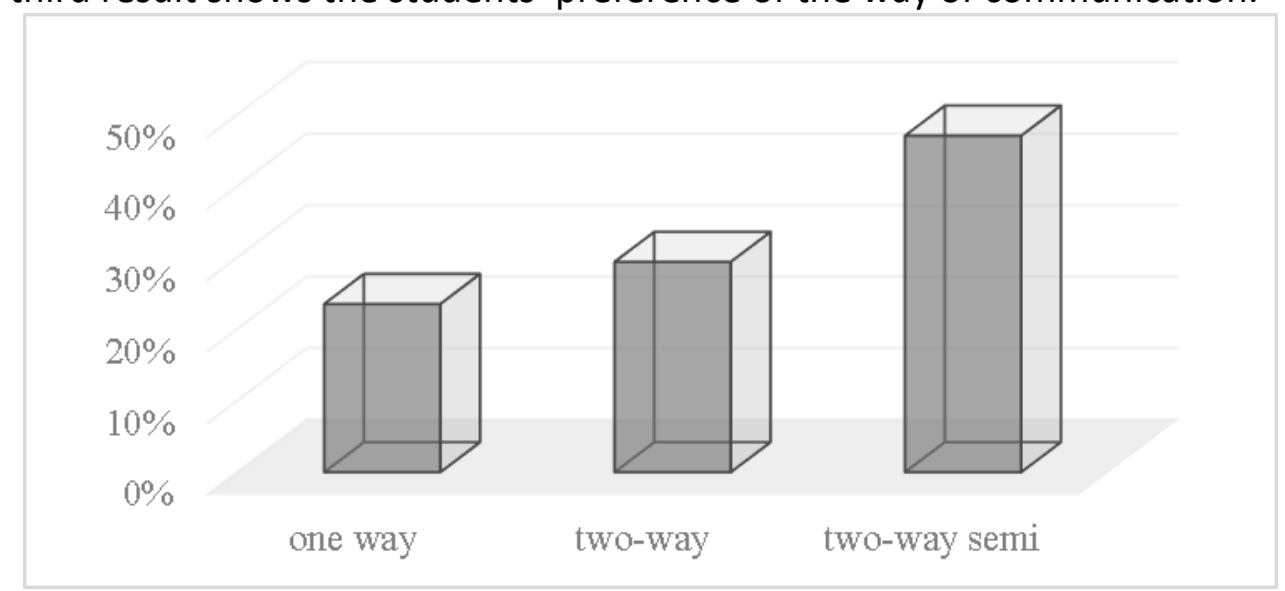

Figure 3. Students' preference of the way of communication

Figure 3 shows that $24 \%$ students choose one way communication in teaching learning process. $29 \%$ students choose two-way communication. $47 \%$ students choose two-way semi communication.

The last is students' preference of the material form of learning.

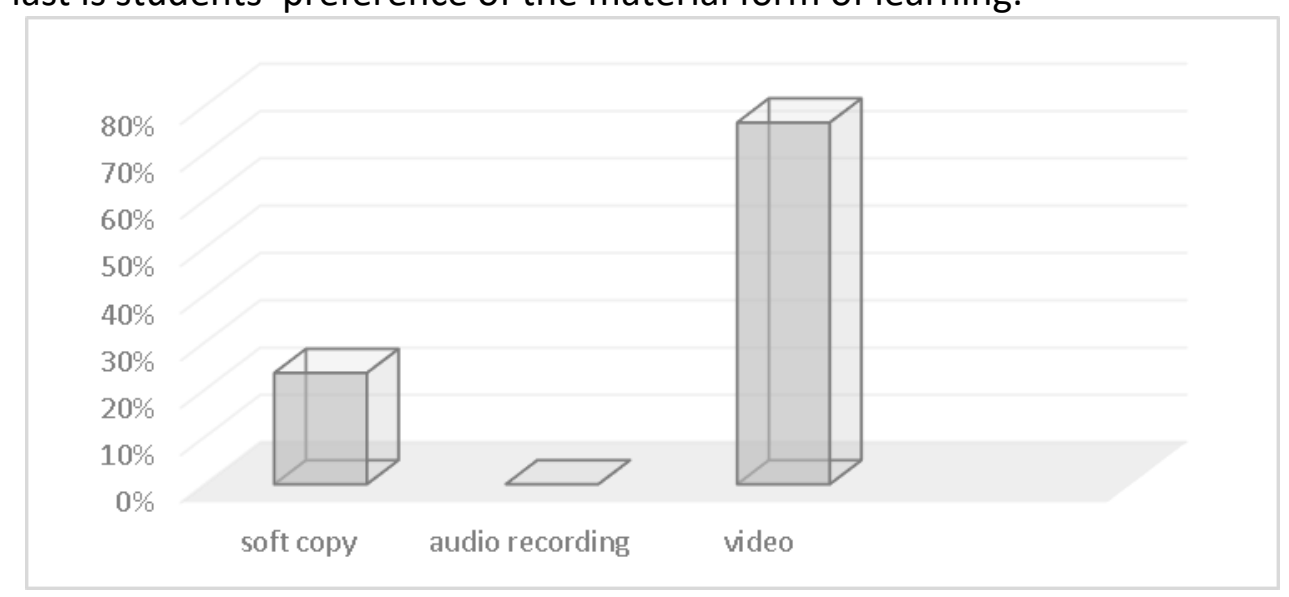

Figure 4. Students' preference of material form

Figure 4 shows that $24 \%$ students are interested in using soft copy as the material form. $76 \%$ students are interested in using video as the material form in teaching learning process. There was no student prefer to audio recording as the material form.

\subsection{Discussion}

Based on responses from respondents, there were several media used during online learning. The media that are frequently used were WhatsApp and Google Classroom. It reveals that the lecturer used more than one media in teaching learning process in New Normal era.

Students of English Education Study Program of UNIVA Labuhanbatu have used WhatsApp before Pandemic. WhatsApp was already in use before the Covid-19 pandemic appeared. They often use WhatsApp as a tool to interact with other people. This makes WhatsApp used more frequently. During pandemic, then Students of English Education 
Study Program of UNIVA Labuhanbatu used Google Classroom as online learning media. The lecturer used Google Classroom because lecturer can manage their course well. They could arrange their material systematically. Students were be given a task through Google Classroom. The lecturer could give an assignment to students' answer. The use of zoom was not as frequent as WhatsApp and Google Classroom. The use of Zoom need much cost. Zoom was be used if the students wanted to present their task.E-mail usually used to send students' task. Google meet, Edmodo, and Moodle never used as learning media. Students said that their lecturers never use those media in teaching learning process.

Students of English Education Study Program of UNIVA Labuhanbatu understood how to operate WhatsApp. Everyday they used this media in their daily life. Even though Google Classroom is a medium that is often used in New Normal, but not all students are able to operate Google Classroom. They do not understand what features are in Google Classroom. They are only able to view the material that has been shared, and upload the results of the answers to assignments assigned by the lecturer. They still do not understand how to make a class, how to make an absence, and create a topic. This is because they are used to being invited into the Google Classroom, while the lecturers are the course lecturers who make the class. It is different with Zoom. Zoom is rarely used but they are better able to operate it. This is because they are often asked by lecturers to make their own meetings. Therefore, the lecturer just needs to join the meeting. They use zoom to make a percentage of a given task. All of students understood how to operate email. They were already familiar with email. There were some tasks should be sent via email. Most of students did not understand how to operate Google Meet, Edmodo, and Moodle. It was because the kecturer never used by lecturer in teaching learning process.

Two-way semi-communication was the type of communication most favored by students of English Education Study Program of UNIVA Labuhanbatu in New Normal era. This was in line with the use of WhatsApp as a medium that was often used in learning in the new normal. On WhatsApp, lecturers and students took turns communicating but continuously, while two-way communication usually used when students were using zoom when presenting assignments.

Lecturer uses variation of material form of learning. This is done to appropriate the material of learning and material form. The lecturer uses soft copy, audio recording, and video. students are interested in using video as the material form in teaching learning process. By using video, the students can replay the material of learning whenever they want. Students are also interested in using soft copy as the material form. The size of soft copy that the lecturer shared is usually not too big. So, students' smartphone can save the soft copy in a big size.

\section{Conclusion}

Online learning is the right policy so that learning can still be carried out in the new normal. There are some online learning media used by English Education Study Program of UNIVA Labuhanbatu in New Normal. The most frequently used are WhatsApp and Google Classroom. The students understand how to operate WhatsApp although not all students understand how to operate Google Classroom. Because of the use WhatsApp is used more often, so students also prefer the type of semi-two-way communication in teaching learning process in New Normal. Video is the most preferred form of material for students of English Education Study Program of UNIVA Labuhanbatu in New Normal. 


\section{References}

Abidin, Z. \& Arizona, K. (2020). Pembelajaran Online Berbasis Proyek Salah Satu Solusi Kegiatan Belajar Mengajar di Tengah Pendemi Covid-19. Jurnal IImiah Profesi Kependidikan.

Hadianti, Siti and Arisandi, Bobi. (2020). The Role of Online English Community during Covid19 Pandemic. Language Literacy: Journal of Linguistics, Literature and Language $\begin{array}{llll}\text { Teaching, } & 4 . & \text { Retrieved } & \text { from }\end{array}$ https://jurnal.uisu.ac.id/index.php/languageliteracy/article/view/3104/pdf

Latip, A. (2020). Peran Literasi Teknologi Informasi dan Komunikasi pada Pembelajaran Jarak Jauh di Masa Pandemi Covid-19. EduTeach: Jurnal Edukasi Dan Teknologi Pembelajaran, $1 . \quad$ Retrieved from https://www.researchgate.net/publication/341868608_PERAN_LITERASI_TEKNOLOGI _INFORMASI_DAN_KOMUNIKASI_PADA_PEMBELAJARAN_JARAK_JAUH_DI_MASA_P ANDEMI_COVID-19

Maulana, F. (2020). Pengaruh Pembelajaran Daring Melalui Google Classroom Terhadap Hasil Belajar Siswa (Survei Pada Mata Pelajaran Ekonomi di Kelas X IIS I SMA Negeri 17 Kota Bandung Tahun Ajaran 2020/2021 (Universitas Pasundan). Retrieved from http://repository.unpas.ac.id/49073/

Melati. (2020). The Use of Zoom Cloud Meeting as anInnovative English Learning Media. International Conference on The Teaching of English and Literature (ICOTEL), 1, 252. Retrieved from https://ejournal.karinosseff.org/index.php/icotel/article/view/89/82

Nashir, M. \& Laili, R. N. (2020). The Use of Zoom Meeting for Distance Learning in Teaching English to Nursing Students during Covid-19 Pandemic. UHAMKA International Conference on ELT and CALL(UICELL), 237. Retrieved from https://journal.uhamka.ac.id/index.php/uicell/article/view/6290/2138

Pratiwi, A. D., Afandi, A., \& Wahyuni, E. S. (2019). Potensi Aplikasi Zoom Cloud Meetings dalam Pembelajaran di Era Digital. Seminar Nasional FKIP 2019:Optimalisasi Kualitas Pembelajaran Abad 21 Di Era Revolusi Industri 4.0 Dalam Menghasilkan Pendidikan Yang Profesional.

Putro, H. Z., et al. (2020). Pola Interaksi Anak Dan Orangtua Selama Kebijakan Pembelajaran Di Rumah. Fitrah: Journal of Islamic Education (FJIE), 1, 126. Retrieved from https://jurnal.staisumatera-medan.ac.id/index.php/fitrah/article/view/12/8

Sahid, H. M. (2020). Pengaruh Media Sosial Whatsapp Terhadap Motivasi Belajar Mahasiswa Di Kabupaten Bogor Wilayah Selatan. JTEV (JURNAL TEKNIK ELEKTRO DANVOKASIONAL, $06 . \quad$ Retrieved from http://ejournal.unp.ac.id/index.php/jtev/article/view/109131/103787 